\section{Australian Journal of \\ Crop Science}

AJCS

ISSN:1835-2707

AJCS 13(05):746-752 (2019)

doi: 10.21475/ajcs.19.13.05.p1490

\title{
Juice technological quality, lignocellulosic physical-chemical attributes and biomass yield from energy cane clones
}

\author{
Ronaldo da Silva Viana* ${ }^{1}$, Bruno Rafael de Almeida Moreira ${ }^{1}$, André May ${ }^{2}$, Celso Tadao Miasaki ${ }^{1}$, José \\ Claudio Caraschi ${ }^{3}$, Maria Gabriela de Oliveira Andrade ${ }^{4}$
}

\author{
${ }^{1}$ São Paulo State University (Unesp), College of Agricultural and Technological Sciences (FCAT), Câmpus of Dracena, \\ Brazil \\ ${ }^{2}$ Agricultural Research Company - Embrapa- Jaguariúna, Brazil \\ ${ }^{3}$ São Paulo State University (Unesp), Campus of Itapeva, Brazil \\ ${ }^{4}$ São Paulo State University (Unesp), Campus of Ilha Solteira (Feis), Brazil
}

\section{*Corresponding author: ronaldo.viana@unesp.br}

\begin{abstract}
Originating from backcrossing generations between wild and commercial sugarcane varieties, "energy cane" technology promises to revolutionize global energetic scenario, once full use of feedstock is allowed. Therefore, the aim of this study was to assess juice technological quality, lignocellulosic physical-chemical composition, and biomass yield of nine energy cane. The experiment had a randomized block design with five replications for each clone (treatment) (VX12-1659, VX12-1658, VX12-1356, VX12-1191, VX121022, VX12-0277, VX12-0201, VX12-0180, and VX12-0046) with five replicates. Following to tillage harvest, stalk samples were assessed for total soluble solids (-Brix; \% juice), sucrose (Pol; \% juice), purity (Prt; \% juice), reducing sugars (RS; \% juice), theoretical sugars recoverable (TSR; $\mathrm{kg} \mathrm{t}^{-1}$ stalks), Pol (\% cane), RS (\% cane), moisture (\% cane), fibers (Fib; \% cane), and dry biomass yield (DBY; $\left.\mathrm{t} \mathrm{ha} \mathrm{a}^{-1}\right)$. The obtained data was subjected to the following statistical tests $(p<0.05)$ : Shapiro-Wilk, Fisher, Tukey, and Pearson's linear correlation. Findings revealed null hypothesis rejection, suggesting the clones significantly affected all assessed traits. The individuals VX12-1659, VX12-1658, VX12-1356, VX12-1191, VX12-1022, and VX12-0277 exhibited the highest ${ }^{\circ}$ Brix (\% juice), Pol (\% juice), Prt (\% juice), TSR, Pol (\% cane), moisture (\% cane), and Fib (\% cane) values. In addition, the clones VX12-1659, VX12-1658, and VX12-1356 resulted in DBY averages higher than other individuals of the population. In fact, all clones showed Type II energy cane typical characteristics due to a low sucrose/fiber ratio. Thus, the energy cane clones are suitable for bioelectricity cogeneration.
\end{abstract}

Keywords: electricity cogeneration; bioenergy; cellulosic ethanol; fiber cane; Saccharum sp.

Abbreviations: TSSj_juice total soluble solids; POLj_ juice sucrose; PRTj_juice purity; RSj_juice reducing sugars; RTS_recoverable theoretical sugars; POLc_cane sucrose; RSc_cane reducing sugars; Uc_cane moisture; FIBC_cane fibers; POLc/FIBc_sucrose/fibers ratio; DBMy_dry biomass yield; FLO_flowering; TIL_tillering; RUS_rusticity; DUM_dumbling; ANOVA_analysis of variance.

\section{Introduction}

Mid-16th century, Portuguese colonizers have introduced some sugarcane (Saccharum sp.) species in Brazil. Since then, this crop has been essential to economic sustainability of this country, where the sugar-energy industry is an international reference. Furthermore, Brazil is second major world sugarcane-derived bioethanol producer, overcame only by the United States, that generates fuel alcohol from maize crop grains (Leal et al., 2013; Matsuoka et al., 2014; Milanez et al., 2015). Belonging to Poaceae botanical family, sugarcane crop is an Asian-originating physiologically $\mathrm{C}_{4}$ plant species grown around the world. Wide physiographic adaptation to tropical and temperate climates, high photosynthetic ability, tolerance against several biotic and abiotic stresses and feasibility to agricultural mechanization are its major advantages, compared to others popular commodities (Silva et al., 2014; Richard and Anderson,
2014). Concerning its economic ends, sugarcane crop produces food for human consumption, such as commercial sugars and alcoholic beverages, as well feed sources for ruminant and non-ruminant domestic animals, such as hydrolyzed silage and forage. Nevertheless, most sugarcane tillage is grown aiming supply added value feedstock to large-scale industrialization of alternative biofuels to the petroleum, natural gas, and coal, such as first generation bioethanol and cellulosic bioethanol (Silva et al., 2014; Richard and Anderson, 2014). In Brazil, sugarcane breeding programs develop varieties with high sucrose/fibers ratio to cover demanding from traditional sugar-energy companies. São Paulo State is the national polo of sugarcane cultivation, and it concentrates on refinery and distillery plants (Kim and Day, 2011; Matsuoka et al., 2012). Currently, steel mills and mills are moving from Southeast to Midwest, North and 
Northeast due to the industrial decentralization, where environmental conditions are damage to agriculture. Consequently, the industry is looking for sugarcane varieties resistant against stress agents, with ability to simultaneously generate bioelectricity, cellulosic ethanol and bio-oil. So, jointly, domestic and international sugarcane genetic breeding centers has given emphasis to the development of energy cane genotypes (Rao et al., 2007; Shields and Boopathy, 2011; Viator and Richard, 2012). Energy cane is a modern technology resulting from several backcrossing generations between wild (S. spontaneum and S. robustum) and commercial (S. officinarum) sugarcane species. In fact, deep root system, large leaf area, strong regrowth and vigorous tillering are rusticity characteristics that allow well support stressing factors, including under marginal lands, where soil fertility and water availability are usually very low, pest attack is more often, heavy metals causes serious phytotoxic problems, and atmospheric pollution reduces gaseous exchanges (Kim and Day, 2011; Matsuoka et al., 2012; Viator and Richard, 2012). Under industrial view point, feedstock quality defines energy cane economic end. The varieties with type I are chosen for cellulosic ethanol production, as they present high sucrose/fibers ratio, whereas varieties type II are preferred for electric cogeneration, due to its low sucrose/fibers ratio (Viator and Richard, 2012; Richard and Anderson, 2014). Therefore, To avoid its unsustainable use, energy cane varieties must be characterized first. This study aimed to assess juice quality attributes, lignocellulosic properties and dry biomass yield of energy cane clones.

\section{Results and Discussion}

\section{Statistical analysis}

Data set distribution was normal by Shapiro-Wilk's test, and homocedasticity of variances for each analyzed parameter was significant by O'Neill-Matthews's test, indicating that analysis of variance results are consistent. According to ANOVA, energy cane clones were significantly different for the juice quality attributes, lignocellulosic properties, as well for the dry biomass yield (Table 1). In summary, Uc and POLC presented greatest coefficient of variation values, unlike FIBC and PRTj. Therefore, local weather conditions have influenced energy cane clones phenotypical behavior.

\section{Juice technological quality}

Table 2 shows results of analysis of variance for juice quality attributes.

\section{Total soluble solids}

The highest levels of TSSj were associated with the clones VX12-1659, VX12-1658, VX12-1356, VX12-1191, VX12-1022, and VX12-0277. One the other hand, clones VX12-0201 and VX12-0180 produced juices with TSSj two-fold below to population mean $\left(10.22 \pm 1.59^{\circ}\right.$ Brix). This clearly demonstrates importance of genetic code to energy cane juice quality. Kim and Day, (2011) reported that grass crops for bioethanol industry such as sugarcane, sweet sorghum and energy cane juice contain the Brix value of 14.00, 12.00 and $11.00^{\circ}$, respectively. Another research on deterioration and fermentation of energy cane juice indicated that clones VG11-X1 and VG11-X2 produces juices with 16.10 and 12.50 ${ }^{\circ}$ Brix values, respectively (Ceccat-Antonini et al., 2017). Some energy cane clones has a low ability with respect to accumulation of soluble solids into stalks, although they produce juice with good physico-chemical quality. For instance, clones W181456, W179460, L91002, and W179458 produce juices with $8.90,9.30,9.40$, and $9.80^{\circ}$ Brix values, respectively (Rao et al., 2007; Matsuoka et al., 2012). In particular, clone L91002 produced juice TSSj with $6.70{ }^{\circ} \mathrm{Brix}$ lower than highest TSSj reported by Ceccat-Antonini et al. (2017), and almost $2.00{ }^{\circ}$ Brix lower than VX12-1356 juice's TSSj. In addition, Richard and Anderson (2014) noted that energy cane provides juice with $10.40^{\circ} \mathrm{Brix}$, supporting our findings. Physiologically, along sugarcane crop ripening process, sucrose and others photoassimilates are intensively moved from stalks to photosynthetic structures, what unleashes a juice with low availability of total soluble solids (Kim and Day, 2011). Often, energy cane juice has lower level of ${ }^{\circ}$ Brix than sugarcane varieties (Rao et al., 2007; Matsuoka et al., 2012). For instance, RB86-7515 and LCP85348 sugarcane commercial varieties produce juices with 14.40 and $16.00^{\circ}$ Brix, i.e., nearly 6.20 and $7.80^{\circ}$ Brix higher than juice's TSSj from clone VX12-0201, respectively. Nevertheless, Ceccat-Antonini et al. (2017), reported juices with high level of ${ }^{\circ}$ Brix can be successfully obtained from energy cane genotypes type I.

\section{Sucrose and Purity}

Clones VX12-1659, VX12-1658, VX12-1356, VX12-1191, $V X 12-1022$, and $V X 12-0277$ were more productive than clones VX12-0180, VX12-0046, and VX12-0201. Specifically, last clone presented four and thirteen points of POLj and PRTj lower than population means $(11.00 \pm 2.35 \%$ and 71.98 $\pm 7.49 \%$ ), respectively. Therefore, due to its most impurity together its lowest total soluble solids content, we have classified clone VX12-0201 as technically unsustainable to second generation ethanol industrialization (Rao et al., 2007; Shields and Boopathy, 2011; Matsuoka et al., 2012). Scientific papers affirms energy cane juice sucrose content is close to 8.90 to $9.60 \%$ (Kim and Day, 2011; Milanez et al., 2015). However, some genotypes produce juices with 7.40 to $12.00 \%$ sucrose, and 58.90 to $74.50 \%$ purity (CeccatAntonini et al., 2017). So, literature information is in accordance with our findings. Sugarcane leaves, solid minerals (stones, gravels, soil colloids etc.), macro and micronutrients, and sugarcane bagasse particles, are impurities that depreciates juice technological quality. Therefore, energy cane juice quality is not only affected by its genetic background, but also by soil fertility and harvest efficiency.

\section{Reducing sugars}

Meeting our expectation, clones VX12-0180, VX12-0046, and VX12-0201 have reached greatest RSj means, which mean how much more sucrose and soluble solids, less availability of glucose and fructose. Milanez et al. (2015) reported energy cane juice reducing sugars content is close to $2.50 \%$, while we found $1.23 \pm 0.18 \%$, only. Genotypic characteristics, local weather, plant old, crop phytosanitary 
Table 1. Summary of statistical analysis for juice quality attributes, lignocellulosic properties and dry biomass yield of energy cane clones.

\begin{tabular}{lllll}
\hline \multirow{2}{*}{ Indicators } & Normality test & Homocedasticity test & Fisher test & \\
\cline { 2 - 5 } & & p-value & \\
\hline TSSj & $0.28^{*}$ & $0.14^{*}, \%$ & 9.55 \\
POLj & $0.19^{*}$ & $0.09^{*}$ & $0.01^{*}$ & 13.94 \\
PRTj & $0.30^{*}$ & $0.17^{*}$ & $0.01^{*}$ & 7.34 \\
RSj & $0.28^{*}$ & $0.18^{*}$ & $0.01^{*}$ & 15.46 \\
RTS & $0.19^{*}$ & $0.11^{*}$ & $0.02^{*}$ & 13.16 \\
POLc & $0.25^{*}$ & $0.14^{*}$ & $0.02^{*}$ & 15.71 \\
RSC & $0.45^{*}$ & $0.34^{*}$ & $0.04^{*}$ & 14.31 \\
Uc & $0.18^{*}$ & $0.04^{*}$ & $0.04^{*}$ & 41.42 \\
FIBc & $0.17^{*}$ & $0.17^{*}$ & $0.04^{*}$ & 7.61 \\
POLC/FIBc & $0.15^{*}$ & $0.08^{*}$ & $0.02^{*}$ & 24.69 \\
DBMy & $0.08^{*}$ & $0.30^{*}$ & $0.03^{*}$ & 9.25 \\
\hline
\end{tabular}

${ }^{1}$ Coefficient of variation (CV); Significance codes: $"(p<0.05)$.

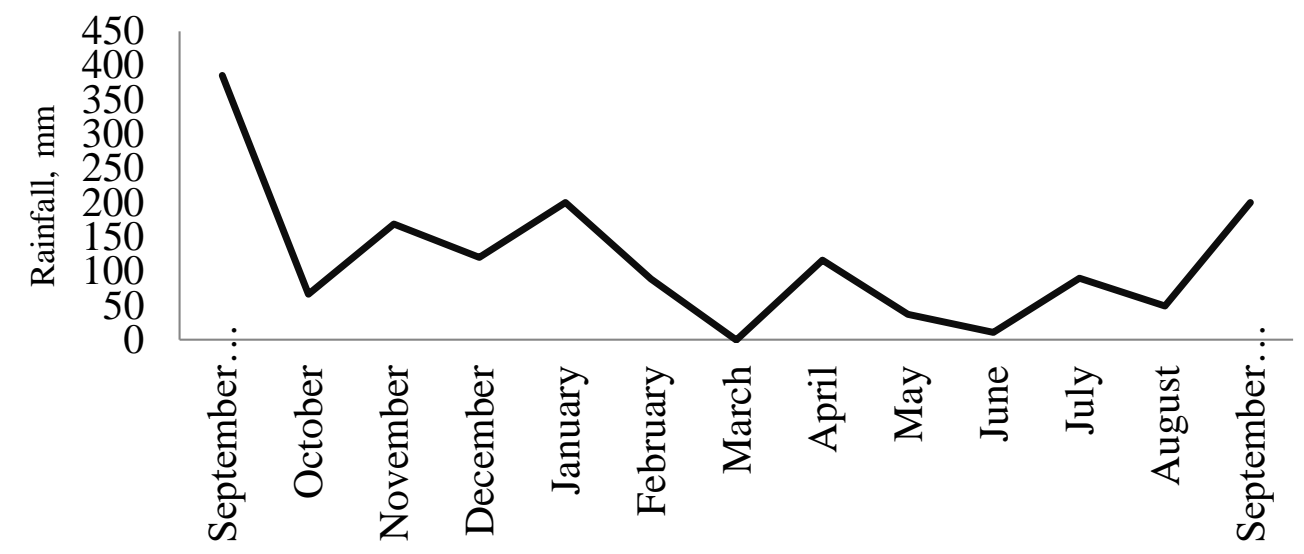

Months

Fig 1. Monthly rainfall over three seasons of energy cane clones experimental cultivation, in the municipality of Paulicéia, São Paulo State, Brazil.

Table 2. Analysis of variance for juice quality attributes of energy cane clones.

\begin{tabular}{llllll}
\hline Clones & TSSj, ${ }^{\circ}$ Brix & POLj, \% & PRTj, \% & RSj, \% & RTS, t ha $^{-1}$ \\
\hline VX12-1659 & $11.25^{\mathrm{a}}$ & $12.43^{\mathrm{ab}}$ & $78.18^{\mathrm{a}}$ & $0.96^{\mathrm{b}}$ & $91.55^{\mathrm{a}}$ \\
VX12-1658 & $10.57^{\mathrm{ab}}$ & $11.38^{\mathrm{ab}}$ & $73.07^{\mathrm{a}}$ & $1.14^{\mathrm{b}}$ & $81.23^{\mathrm{ab}}$ \\
VX12-1356 & $11.59^{\mathrm{a}}$ & $12.88^{\mathrm{a}}$ & $75.29^{\mathrm{a}}$ & $1.06^{\mathrm{b}}$ & $90.60^{\mathrm{a}}$ \\
VX12-1191 & $10.83^{\mathrm{a}}$ & $11.99^{\mathrm{ab}}$ & $76.96^{\mathrm{a}}$ & $1.00^{\mathrm{b}}$ & $86.51^{\mathrm{ab}}$ \\
VX12-1022 & $10.30^{\mathrm{ab}}$ & $11.51^{\mathrm{ab}}$ & $72.56^{\mathrm{a}}$ & $1.16^{\mathrm{b}}$ & $79.90^{\mathrm{abc}}$ \\
VX12-0277 & $10.79^{\mathrm{a}}$ & $12.50^{\mathrm{ab}}$ & $77.30^{\mathrm{a}}$ & $0.99^{\mathrm{b}}$ & $86.56^{\mathrm{ab}}$ \\
VX12-0201 & $8.22^{\mathrm{abc}}$ & $7.29^{\mathrm{c}}$ & $59.13^{\mathrm{b}}$ & $1.62^{\mathrm{a}}$ & $58.11^{\mathrm{c}}$ \\
VX12-0180 & $8.60^{\mathrm{bc}}$ & $9.38^{\mathrm{bc}}$ & $67.95^{\mathrm{ab}}$ & $1.31^{\mathrm{ab}}$ & $66.02^{\mathrm{bc}}$ \\
VX12-0046 & $9.86^{\mathrm{abc}}$ & $9.65^{\mathrm{bc}}$ & $67.42^{\mathrm{ab}}$ & $1.33^{\mathrm{ab}}$ & $72.45^{\mathrm{abc}}$ \\
\hline
\end{tabular}

Means followed by same letters not differ by Tukey's test $(p<0.05)$.

Table 3. Analysis of variance for lignocellulosic properties and dry biomass yield of energy cane clones.

\begin{tabular}{lllllll}
\hline Clones & POLc, $\%$ & RSc, \% & Uc, \% & FIBc, \% & POLc/FIBc & DBMy, t ha $^{-1}$ \\
\hline VX12-1659 & $8.87^{\mathrm{a}}$ & $0.67^{\mathrm{c}}$ & $8.02^{\mathrm{b}}$ & $22.04^{\mathrm{b}}$ & $0.42^{\mathrm{a}}$ & $106.12^{\mathrm{a}}$ \\
VX12-1658 & $7.70^{\mathrm{ab}}$ & $0.77^{\mathrm{bc}}$ & $10.00^{\mathrm{b}}$ & $24.77^{\mathrm{ab}}$ & $0.32^{\mathrm{ab}}$ & $95.48^{\mathrm{ab}}$ \\
VX12-1356 & $8.72^{\mathrm{ab}}$ & $0.72^{\mathrm{bc}}$ & $8.24^{\mathrm{b}}$ & $24.11^{\mathrm{ab}}$ & $0.36^{\mathrm{ab}}$ & $90.42^{\mathrm{ab}}$ \\
VX12-1191 & $8.32^{\mathrm{ab}}$ & $0.69^{\mathrm{bc}}$ & $8.36^{\mathrm{b}}$ & $22.83^{\mathrm{ab}}$ & $0.37^{\mathrm{ab}}$ & $87.21^{\mathrm{b}}$ \\
VX12-1022 & $7.59^{\mathrm{ab}}$ & $0.75^{\mathrm{bc}}$ & $10.96^{\mathrm{b}}$ & $26.02^{\mathrm{a}}$ & $0.30^{\mathrm{ab}}$ & $84.28^{\mathrm{b}}$ \\
VX12-0277 & $8.36^{\mathrm{ab}}$ & $0.66^{\mathrm{c}}$ & $8.05^{\mathrm{b}}$ & $24.77^{\mathrm{ab}}$ & $0.34^{\mathrm{ab}}$ & $84.61^{\mathrm{b}}$ \\
VX12-0201 & $5.00^{\mathrm{c}}$ & $1.09^{\mathrm{a}}$ & $26.26^{\mathrm{a}}$ & $24.08^{\mathrm{ab}}$ & $0.21^{\mathrm{b}}$ & $81.43^{\mathrm{b}}$ \\
VX12-0180 & $6.04^{\mathrm{bc}}$ & $0.86^{\mathrm{abc}}$ & $18.31^{\mathrm{ab}}$ & $26.17^{\mathrm{a}}$ & $0.23^{\mathrm{b}}$ & $82.39^{\mathrm{b}}$ \\
VX12-0046 & $6.65^{\mathrm{abc}}$ & $0.91^{\mathrm{ab}}$ & $14.09^{\mathrm{b}}$ & $23.22^{\mathrm{ab}}$ & $0.29^{\mathrm{ab}}$ & $81.63^{\mathrm{b}}$ \\
\hline
\end{tabular}

Means followed by same letters not differ by Tukey's test $(p<0.05)$. 
Table 4. Matrix of linear correlation for juice quality attributes, lignocellulosic properties and dry biomass yield of energy cane clones.

\begin{tabular}{|c|c|c|c|c|c|c|c|c|c|}
\hline$X-Y$ & POLj & PRTj & RSj & TSR & RSC & Uc & FIBC & POLC & DBMy \\
\hline TSSj & $0.94^{*}$ & $0.79^{*}$ & $-0.79^{*}$ & $0.97^{*}$ & $-0.73^{*}$ & $-0.83^{*}$ & $-0.47^{\mathrm{ns}}$ & $0.97^{*}$ & $0.51^{\text {ns }}$ \\
\hline POLj & & $0.92^{*}$ & $-0.92^{*}$ & $0.97^{*}$ & $-0.90^{*}$ & $-0.91^{*}$ & $-0.26^{\mathrm{ns}}$ & $0.98^{*}$ & $0.49^{\text {ns }}$ \\
\hline PRTj & & & $-0.99^{*}$ & $0.88^{*}$ & $-0.98^{*}$ & $-0.93^{*}$ & $-0.30^{\mathrm{ns}}$ & $0.91^{*}$ & $0.47^{\text {ns }}$ \\
\hline RSj & & & & $-0.88^{*}$ & $0.98^{*}$ & $0.93^{*}$ & $0.30^{\text {ns }}$ & $-0.91^{*}$ & $0.46^{\mathrm{ns}}$ \\
\hline TSR & & & & & $-0.84^{*}$ & $-0.86^{*}$ & $-0.47^{\mathrm{ns}}$ & $0.99^{*}$ & $0.51^{\mathrm{ns}}$ \\
\hline RSc & & & & & & $0.93^{*}$ & $0.13^{\text {ns }}$ & $-0.86^{*}$ & $0.42^{\text {ns }}$ \\
\hline Uc & & & & & & & $0.22^{\text {ns }}$ & $-0.88^{*}$ & $0.47^{\mathrm{ns}}$ \\
\hline $\mathrm{FIBC}$ & & & & & & & & $-0.45^{\mathrm{ns}}$ & $-0.30^{\mathrm{ns}}$ \\
\hline POLC & & & & & & & & & $0.51^{\mathrm{ns}}$ \\
\hline
\end{tabular}

Significance codes: ${ }^{*}(p<0.05) ;{ }^{n s}(p \geq 0.05)$.

Table 5. List of energy cane clones and its agronomic characteristics.

\begin{tabular}{|c|c|c|c|c|c|c|c|}
\hline \multirow{2}{*}{ Clones } & \multicolumn{3}{|c|}{ Phytopathological aspect } & \multicolumn{4}{|c|}{ Morphophysiological aspect } \\
\hline & Smut $^{1}$ & Rust $^{2}$ & Leaf scald $^{3}$ & FLO & TIL & RUS & DUM \\
\hline VX12-1659 & Resistant & Resistant & Resistant & No & High & Medium & No \\
\hline VX12-1658 & Susceptive & Resistant & Resistant & High & High & Low & Sporadic \\
\hline VX12-1356 & Tolerant & Resistant & Resistant & Low & High & Medium & Sporadic \\
\hline VX12-1191 & Resistant & Resistant & Resistant & No & High & Low & Frequent \\
\hline VX12-1022 & Tolerant & Resistant & Resistant & No & High & Medium & No \\
\hline VX12-0277 & Tolerant & Resistant & Resistant & No & High & Medium & No \\
\hline VX12-0201 & Susceptive & Intermediate & Resistant & No & High & Low & No \\
\hline VX12-0180 & Resistant & Resistant & Resistant & No & High & Low & No \\
\hline VX12-0046 & Tolerant & Resistant & Resistant & No & Medium & Low & Sporadic \\
\hline
\end{tabular}

Scientific names : ${ }^{1}$ Ustilago scitaminea; ${ }^{2}$ Puccinia spp.; ${ }^{3}$ Xanthomonas albilineans.

status, and soil fertility management are possible causes for this large difference. As known, glucose is an essential substrate to cellulosic ethanol industrialization. Under low levels; however, it reduces yeasts-performed sugar fermentation efficiency, making feedstock unsuitable for this end (Ceccat-Antonini et al., 2017). Therefore, all tested energy cane clones were classified as technically unfit to second generation ethanol distillation.

\section{Recoverable theoretical sugars}

As previously noted for TSSj and POLj, clones VX12-1659, VX12-1658, VX12-1356, VX12-1191, VX12-1022, and VX120277 were associated with best RTS means. On the other hand, RTS yields of the clones VX12-0201, VX12-0180, and VX12-0046 were lower than population mean (79.11 \pm 15.21 $\left.\mathrm{kg} \mathrm{t}^{-1}\right)$. RTS was dramatically influenced by juice quality, such as TSSj, POLc and RSj, which explains above-cited results for the clones VX12-1659, VX12-1658, VX12-1356, VX12-1191, $V X 12-1022$, and VX12-0277, whose juices have presented highest levels of sucrose and total soluble solids, as well worse reducing sugars means. Under sphere of sugar-energy chain, sugarcane producers are basically paid for the RTS yield (Viana et al., 2017). We assume this economic measure could be more interesting for analyze energy clone varieties type I than energy cane varieties type II, whose sucrose yield is less important than dry biomass yield and fibers yield. For energy cane, biomass lignocellulosic quality is industrially more attractive than juice technological quality. However, we emphasize that POLj, TSSj, RSj, and RTS may be important traits for the selection of individuals with multi economic ends, aiming production of cellulosic ethanol, biooil, and biomass-to-liquid biofuels, simultaneously. Viator and Richard (2012) reported energy cane biomass can be fully used.

\section{Lignocellulosic properties}

Table 3 shows analysis of variance results for lignocellulosic properties.

\section{Sucrose and Reducing sugars}

Clones VX12-1659, VX12-1658, VX12-1356, VX12-1191, $V X 12-1022$, and $V X 12-0277$ reached highest POLc means, whereas clones VX12-0180, VX12-0046, and VX12-0201 provided POLc lower than population mean $(7.47 \pm 1.24 \%)$. In addition, level of cane's POLc from clone VX12-1659 was almost four points higher than cane's POLc from clone VX120201, which was associated with worst POLc mean. In general, POLc of the population was $0.80 \pm 0.13 \%$.

\section{Moisture}

Clone VX12-0201 produced a lignocellulosic biomass with highest moisture. This result explains more accumulation of monosaccharides into stalks, since sucrose hydrolyzing process is directly affected by the biomass hydration degree. The clones VX12-1659, VX12-1658, VX12-1356, VX12-1191, and VX12-0277 displayed four percentage points of Uc lower than population mean $(12.48 \pm 7.68 \%)$. Energy cane varieties type II with high moisture content, were not feasible for electricity cogeneration, since its lignocellulosic biomass combustion-derived thermal energy is preferentially spent on water molecules consumption. Hence, low volume of steam is generated, restricting process of energetic conversion from thermal energy to electric (Bahadori et al., 
2014). In this sense, clones VX12-0201, VX12-0180, and VX12-0046 are less indicative for electricity large-scale cogeneration plants than other clones, since they supplied a lignocellulosic feedstock with two, four, and fourteen percentage points of Uc upper than population mean, approximately.

\section{Fibers and sucrose/fibers ratio}

Statistically, clones VX12-1022, VX12-0277, and VX12-0180 produced a lignocellulosic biomass more fibrous than VX121659 clone. In general, population provided bagasse with $24.34 \pm 1.23 \%$ fibers. With respect to POLc/FIBc ratio, clone VX12-1659 was statistically superior to clones VX12-0180, and VX12-0046. Energy cane type $I$ is known by its high sucrose/fiber ratio (close to 13/18), while energy cane type II has a low sucrose/fibers ratio (close to 6/30) (Kim and Day, 2011; Matsuoka et al., 2012; Viator and Richard, 2012). Therefore, we have classified all tested clones as energy cane clones type II, since population's sucrose/fibers ratio was $7.47 \pm 1.71 / 24.15 \pm 2.14$. Ceccat-Antonini et al. (2017) noted that clones VG11-X1 and VG11-X2 generated a lignocellulosic biomass with 20.30 and $13.80 \%$ fibers. These results are in accordance with our findings, as well with Rao et al. (2007), Kim and Day (2011), and Matsuoka et al. (2012), who observed the energy clone bagasse of 24.25, 16.70 , and $22.50 \%$ fibers, respectively. Although to be qualifies as an anti-economical parameter, fibers act like natural mechanical barriers, protecting sugarcane crop against biotic and abiotic agents, such as heat stress, water stress, winds, and pests attack, which induces sucrose degrading, plant tumbling, among others negative effects to feedstock quality. Furthermore, it determines sugarcane tillage commercial cycle longevity. In function of its higher fibers-induced rusticity, energy cane genotypes allow 8 to 10 harvest, whereas conventional sugarcane varieties allow 4 to 5 harvest only (Kim and Day, 2011; Matsuoka et al., 2014; Milanez et al., 2015). Morpho-anatomically, fibers are plant tissues structured by cellulose, hemicellulose, glycoproteins, and lignin, containing organic molecule with oxygen, hydrogen and carbon atoms with great calorific value. Therefore, energy cane lignocellulosic biomass has many interesting points for electricity co-generation mills. Due to changes in current world energy scenario, mainly in relation to replacement of non-renewable fuels to bioelectricity sources, energy cane breeding programs have invested on development of specific genotypes to produce primary energy from lignocellulosic biomass. Hence, within few years, energy cane will tend to produce feedstock with more fibers than sucrose (Matsuoka et al., 2014).

\section{Dry biomass yield (DBMy)}

Clones VX12-1659, VX12-1658, and VX12-1356 reached best DBMy mean, whereas clones VX12, 1022, VX12-0277, VX1202011, VX12-0046, and VX12-0180 presented inferior agronomic performance to population mean $(77.42 \pm 10.43 \mathrm{t}$ $\mathrm{ha}^{-1}$ ). Matsuoka et al. (2014) noted that energy cane biomass yield is upper than $60.00 \mathrm{t} \mathrm{ha}^{-1}$, supporting our findings, as well as study of Richard and Anderson (2014), who reported that $\mathrm{L791002}$ clone biomass yield is close to $66.60 \mathrm{t} \mathrm{ha}^{-1}$. According to Carvalho-Netto et al. (2014), energy cane and Napier-grass (Pennisetum spp.) produced 19.00 a $45.00 \mathrm{t} \mathrm{ha}^{-1}$ dry biomass, respectively. The clones VX12-1659, VX121658 , and $V X 12-1356$ produced $40.50,28.90$, and 25.90 tons more biomass than clones than reported in literature, where DBMy mean is close to $57.10 \mathrm{t} \mathrm{ha}^{-1}$ dry biomass. The high biomass yield is one of the major adjectives for energy cane. Under grow optimal conditions, it allows $177.00 \mathrm{t} \mathrm{ha}^{-1}$.

\section{Linear correlation}

Table 4 shows Pearson's results for linear correlations between juice quality attributes, lignocellulosic properties and dry biomass yield

TSSj was positively correlated with POLj, RTS, and POLc, but negatively correlated with RSj, RSc, Uc, and FIBc. Such correlations affirm that hydrated biomass induces sucrose hydrolysis, results in high accumulation of fructose and glucose into both juice and stalks. For this reason, VX120201, VX12-0180, and VX12-0046 clones, with greatest levels of moisture, presented the lowest RTS, POLc, POLj, PRTj, and TSSj yelds, but the highest RSj, and RSc means. Silva et al. (2008); Ahmed et al. (2010); Audilakshimi et al. (2010) have checked positive correlations between total soluble solids, sucrose, and purity, supporting our findings. POLj was positively correlated with $\mathrm{PRTj}$, but negatively correlated with FIBc. Khan et al. (2012), studied correlations between sugarcane agronomic attributes. Tahir et al. (2014), analyzed selection indexes of sugarcane varieties and recorded a positive correlation between sucrose and purity. Sugarcane juice purity is calculated by means $\mathrm{POLC} /{ }^{\circ} \mathrm{Brix}$ ratio, indirectly. So, more sucrose and greatest purity were observed from VX12-1659, VX12-1658, VX12-1356, VX121191, VX12-1022, and VX12-0277 clones, where juices allowed the highest sucrose and purity contents. As known, more fibrous sugarcane varieties have less sucrose accumulation ability, since they move its sugars from parenchyma in to the cell wall, what explains POLC and FIBC correlation. Unfortunately, juice quality attributes and lignocellulosic properties were not correlated with DBMy, significantly. Statistical tools, such as Pearson's test, can be successfully used to improve sugarcane feedstock quality by genetic breeding, plant physiology and soil fertilizing management strategies (Júnior et al., 2008; Silva et al., 2008; Khan et al., 2012).

\section{Materials and Methods}

\section{Site of study}

The research was carried out at the experimental area of the Usina Caeté, in the municipally of Paulicéia, São Paulo State, Brazil, including three harvests. According to Köppen-Geiger, regional climate is $A w$, i.e. rainy summer and dry winter. Furthermore, soil is a dystrophic yellow-red Latosol.

\section{Experimental design}

The experiment was set up in a randomized block design, with five replications for each clone: VX12-1659, VX12-1658, VX12-1356, VX12-1191, VX12-1022, VX12-0277, VX12-0201, and VX12-0180. Plots were planned with twenty-lines of plantation, with $10 \mathrm{~m}$ length, spaced at $0.5 \mathrm{~m}$. 


\section{Clones origination}

Originating from pre-sprouted seedlings, clones were belonged to the sugarcane genetic breeding program performed by Biovertis/Granbio company. Table 5 shows its agronomic characteristics.

\section{Soil preparation and clone planting}

In July 2014, soil acidity and fertility were improved with dolomitic limestone $\left(2.0 \mathrm{t} \mathrm{ha}^{-1}\right)$ and NPK $\left(0.6 \mathrm{t} \mathrm{ha}^{-1}\right)$ commercial fertilizer, respectively. Two months later, early sugarcane season, seedlings were manually transplanted under rainfall good conditions. From second and third harvest, tillage fertilizing management was performed as the recommendations of Embrapa (2013). Figure 1 shows average monthly rainfall over experimental cycle.

\section{Harvest and technical analysis}

In September 2017, before flowering period, three-year-old plants were mechanically harvested from ten-central lines of plantation of each plot. After leave removal, a hydraulic press (24.5 $\mathrm{MPa}$ ) was used for sugarcane juice extraction from stalks. As the guide published by (Consecana, 2006), bagasse and juice samples were assessed for total soluble solids (TSS), sucrose (POLj; POLC), purity (PRTj), reducing sugars (RSj; RSC), recoverable theoretical sugars (RTS), moisture (Uc), fibers (FIBC), and dry biomass yield (DBMy).

\section{Statistical analysis}

Data set was statistically analyzed by Shapiro-Wilk, O'NeillMathews, Fisher, Tukey and Pearson tests at 5\% of significance, with aid of the R Core Team software version 3.3.1.

\section{Conclusion}

VX12-1659, CX12-1648, and VX12-1191 clones produced greatest amounts of dry biomass. Juices from VX12-0201, VX12-0180, and VX12-0046 clones were chemically poorest, with lowest total soluble solids and sucrose contents. VX120201 clone produced lignocellulosic feedstock with highest moisture and reducing sugars contents, as well generating lowest recoverable theoretical sugars yield. Due to low sucrose/fibers ratio, clones were classified as energy cane type II, being preferable for electricity co-generation than to cellulosic ethanol industrialization.

\section{Acknowledgements}

Thanks to the Biovertis/GranBio Company that provided access to the data for the execution of the research.

\section{References}

Ahmed AO, Obeid A, Dafallah B (2010) The influence of characters association on behavior of sugarcane genotypes (Saccharum spp.) for cane yield and juice quality. World J Agric Sci. 6(2):207-211.
Audilakshmi S, Mall AK, Swarnalatha M, Seetharama N (2010) Inheritance of sugar concentration in stalk (brix), sucrose content, stalk and juice yield in sorghum. Biomass Bioenergy. 34(6):813-820.

Bahadori A, Zahedi G, Zendehboudi S, Jamili A (2014) Estimation of the effect of biomass moisture content on the direct combustion of sugarcane bagasse in boilers. Int J Sust Energy. 33(2):349-356.

Carvalho-Netto OV, Bressiani JA, Soriano HL, Fiori CS, Santos JM, Barbosa GV, Pereira GA (2014) The potential of the energy cane as the main biomass crop for the cellulosic industry. Chem Biol Technol Agric. 1(1):20.

Ceccato-Antonini SR, Bassi APG, Paraluppi AL, Santos EGD, Matsuoka S (2017) Deterioration and fermentability of energy cane juice. Ciênc Rural, 47(9): e20160860.

EMBRAPA - Empresa Brasileira de Pesquisa Agropecuária (2013) Sistema brasileiro de classificação de solos. Embrapa, Brasil.

Júnior C, Marques MO, Tasso Júnior LC (2008) Efeito residual de quatro aplicações anuais de lodo de esgoto e vinhaça na qualidade tecnológica da cana-de-açúcar. Eng Agric. 28(1):196-203.

Khan IA, Bibi S, Yasmin S, Khatri A, Seema N, Abro SA (2012) Correlation studies of agronomic traits for higher sugar yield in sugarcane. Pak J Bot. 44(3):969-971.

Kim M, Day D (2011) Composition of sugar cane, energy cane, and sweet sorghum suitable for ethanol production at Louisiana sugar mills. J Ind Microbiol Biotechnol. 38:803-807.

Leal MRLV, Walter AS, Seabra JEA (2013) Sugarcane as an energy source. Biomass Conv Bioref. 3(1):17-26, 2013.

Leite RCC (2008) Fotossíntese e Cana-energia. Ciênc Cultura. 60(3):4-6.

Matsuoka S, Bressiani J, Maccheroni W, Fouto I (2012) Bioenergia da cana.(ed) Cana-de-açúcar: Bioenergia Aç e Álc. 1:548-576.

Matsuoka S, Kennedy AJ, Santos EGDD, Tomazela AL, Rubio LCS (2014) Energy cane: its concept, development, characteristics, and prospects. Advances Botany. 2014:1- 13.

Milanez AY, Nyko D, Valente MS, Sousa LC, Bonomi AMFL, Jesus CDFD, Junqueira TL (2015) De promessa à realidade: como o etanol celulósico pode revolucionar a indústria da cana-de-açúcar: uma avaliação do potencial competitivo e sugestões de política pública. BNDES Set. 41:(237-294).

Rao PS, Davis H, Simpson CARL (2007) New sugarcane varieties and year round sugar and ethanol production with bagasse-based cogeneration in Barbados and Guyana. Int Soc of sugar cane Technol. 26:169-1176.

Richard EP, Anderson, WF (2014) Sugarcane, energy cane and napier grass. Cell Energy Cropp Syst. 1:91-108.

Shields S, Boopathy R (2011) Ethanol production from lignocellulosic biomass of energy cane. Int Biodet Biodeg. 65(1):142-146.

Silva MDA, Silva JAGD, Enciso J, Sharma V, Jifon J (2008) Yield components as indicators of drought tolerance of sugarcane. Sci Agric. 65(6):620-627. 
Silva MDA, Arantes MT, Rhein AFDL, Gava GJ, Kolln OT (2014) Potencial produtivo da cana-de-açúcar sob irrigação por gotejamento em função de variedades e ciclos. Rev Bras Eng Agríc Amb. 18(3):241-249.

Tahir M, Khalil IH, McCord PH, Glaz B (2014) Character association and selection indices in sugarcane. American J Exp Agric. 4(3):336-348.
Viana RS, May A, Mateus GP, Neto ADR, Lopes PRM (2017) Aspectos tecnológicos de sorgo-sacarino submetido à aplicação de maturadores químicos. Cient. 45(3):204-213.

Viator RP, Richard EP (2012) Sugar and energy cane date of planting effects on cane, sucrose, and fiber yields. Biomass Bioenergy. 40:82-85. 